\title{
Sex, Gender and the Making of the 'Enemy Within' in Cold War Argentina
}

\author{
VALERIA MANZANO*
}

Abstract. This article studies the unfolding of a broad conservative bloc amidst the politico-cultural battles that took place in Cold War Argentina. Focusing on the unexplored gendered, sexual and generational dimensions of the figure of the 'enemy within', the article shows that this figure was at the core of a project which coincided with authoritarian practices emanating from the state and also from segments of civil society. The creation of that figure had significant effects, not only in the political but also in the educational and cultural realms, including the imposition of censorship and the delineation of restrictive sexual policies. Moreover, it conditioned the ways in which political repression developed in the context of I 970 state terrorism.

Keywords: 'enemy within', Argentina, gender and sexuality, modernisation, right-wing politics, state terrorism

\section{Introduction}

In July 196I, the conservative Catholic group Organización Americana de Salvaguardia Moral (American Organization for the Safeguarding of Morality, OASMO) organised a conference to exert pressure on the Argentine national authorities to 'defend youth from the moral decay' that, they argued, was sweeping across the country. The press publicised the event widely, and it also had the endorsement of President Arturo Frondizi (1958-62), head of one of the purportedly most democratic, development-oriented administrations that had ruled the country between I955, when a military coup d'état overthrew Juan Perón's regime and banned his political movement, and 1973, the year of the first elections in which a candidate could run again on a Peronist ticket. Frondizi praised OASMO's commitment to struggle against 'youth's

Valeria Manzano is associate professor of History at the Universidad de San Martín and associate researcher at the Consejo Nacional de Investigaciones Científicas y Técnicas (CONICET), Argentina. Email: amanzano@umail.iu.edu.

* The author has presented earlier versions of this essay at the XIV Berkshire Conference on the History of Women and at the Núcleo de Estudios sobre Historia Reciente, and would like to express her gratitude to all the colleagues who made extremely valuable contributions. Likewise, she would like to thank the JLAS reviewers and editors for their wonderfully thorough comments. The research and writing of this article were assisted by an ACLS New Faculty Fellows award, with the support of the Andrew Mellon Foundation. 
weakening morals', a problem that, he thought, paved the way for the spread of communism. ${ }^{1}$ In late 1975 , surely unaware of those earlier efforts, groups of middle-class neighbours from both Buenos Aires and distant Patagonia reproduced the same ideas. Since the civilian government of Isabel Perón had already authorised the military to repress social and political activities, these groups of neighbours wrote to the minister of the interior asking for police surveillance in their communities, which they viewed as threatened by youth engaged in either 'subversive actions', 'drug consumption', 'sexual orgies' or all of these. ${ }^{2}$ They constructed a link between youth, sexual deviancy and subversion, which they saw as the characteristics of the 'enemy within' that jeopardised the fabric of the national body. It was this national fabric that the military junta which imposed the country's most dramatic military dictatorship in 1976 supposedly came to heal.

The making of the 'enemy within' in Argentina echoed similar developments worldwide during the Cold War. As scholars have shown, in the United States in the I950s, for example, the 'Red Scare' melded with fears of 'deviant sexuality' (including extra- and premarital sex, homosexuality and 'sex pathologies'), leading to a politics of containment of both political and sexual liberation. ${ }^{3}$ In those Cold War projects, the nuclear family, endowed with clear-cut gender divides, would constitute the baseline of social stability, thus becoming a chief political goal as well. ${ }^{4}$ In Latin America, those projects gained full strength in the 1960s, when the repercussions of the Cuban Revolution accelerated the implementation of national security ideologies. Anti-communist in essence, these ideologies justified and oriented repressive policies aimed at achieving popular demobilisation and securing 'development' as well as preserving so-called Western or Christian values from the threats posed by external or internal enemies. ${ }^{5}$ The scholarship on national

I 'Un congreso contra la Dolce Vita', La Razón, 22 Aug. 1961, p. 3.

2 'Adriana Sesto y otros al Ministro del Interior', file no. I60785, box 26; 'Marina Santos y otros al Ministro del Interior', file no. 172222, box 13, Expedientes Generales - Sección Intermedia, Archivo General de la Nación.

3 Estelle Freedman, "Uncontrolled Desires": The Response to the Sexual Psychopath, 1920-1960', Journal of American History, 74: I (June 1987), pp. 83-106; John D’Emilio, 'The Homosexual Menace: The Politics of Sexuality in Cold War America', in Christina Simmons and Kathy Peiss (eds.), Passion and Power: Sexuality in History (Philadelphia, PA: Temple University Press, 1989), pp. 226-43; David K. Johnson, The Lavender Scare: The Cold War Persecution of Gays and Lesbians in the Federal Government (Chicago, IL: University of Chicago Press, 2004).

${ }^{4}$ See Elaine Tyler May's pioneering study, Homeward Bound: American Families in the Cold War Era (New York: Basic Books, 1988); and Joanne Meyerowitz (ed.), Not June Cleaver: Women and Gender in Postwar America, 1945-1960 (Philadelphia, PA: Temple University Press, 1994).

5 Prudencio García, El drama de la autonomía militar en la Argentina (Madrid: Alianza, I 995), pp. 39-40; David Pion-Berlin, 'Latin American National Security Doctrines: Hardand Soft-line Themes', Armed Forces and Society, i 5: 3 (1989), pp. 4 I I-29. 
security ideologies has pointed out that the meanings of the 'enemy within' remained unsubstantiated. However, this finding led scholars to overlook the study of the contextual meanings of these terms. Benjamin Cowan, for example, has shown that, in Brazil, subversion and the 'enemy within' were associated with gendered and sexual hazards, which were viewed as a threat to the nation's youth. ${ }^{6} \mathrm{~A}$ similar rationale spread in Argentina, and it went beyond the realm of the state and military quarters.

The making of the 'enemy within' in I 960 s and I970s Argentina built on and transformed previous conservative traditions. As Sandra McGee Deutsch has shown, in the early twentieth century, groups from the 'far-right' and conservative intellectuals reacted against the 'egalitarian and liberating tendencies of the moment' as well as other factors that, they believed, undermined the socio-economic order based on the principles of authority, private property and nationhood.7 In 1960s and 1970s Argentina, the challenges to the social, political and cultural order acquired manifold meanings and they were expressed, for example, in the shaping of a multilayered youth culture of contestation articulated through the notions of 'liberation' and 'revolution'. ${ }^{8}$ Alongside the development of that culture, and trying to set limits to the conditions that made it possible, an informal conservative bloc emerged. At its most extreme, it included elitist groups of intellectuals associated with Catholic, right-wing nationalism. Noticeable in the ideological formation of the military, these groups have thus far received a greater share of scholarly attention. ${ }^{9}$ However, sharing these groups' concerns with the preservation of order, hierarchy and authority, another conservative layer burgeoned, one that sought to defend what it viewed as the best antidote against communism: the family. As in Chile, Brazil and Mexico, Cold War anti-communism made inroads among women. Called to preserve their role as guardians of the family institution, they were visible actors in their assumed war. ${ }^{\circ}$ Along with right-wing intellectuals and politicians, military ideologues

${ }^{6}$ Ben Cowan, 'Sex and the Security State: Gender, Sexuality, and "Subversion" in Brazil's Escola Superior de Guerra, 1964-1985', Journal of the History of Sexuality, 16: 3 (2007), pp. 459-6I.

7 Sandra McGee Deutsch, Las Derechas: The Extreme Right in Argentina, Chile, and Brazil, 1890-1939 (Stanford, CA: Stanford University Press, 1999), p. 3.

${ }^{8}$ See Valeria Manzano, The Age of Youth in Argentina: Culture, Politics, and Sexuality from Perón to Videla (Durham, NC: University of North Carolina Press, 2014).

9 David Rock, Authoritarian Argentina: The Nationalist Movement, Its History, and Its Impact (Berkeley, CA: University of California Press, 1993), chap. 7; Jorge Saborido, 'El nacionalismo argentino en los años de plomo: la revista Cabildo y el Proceso de Reorganización Nacional', Anuario de Estudios Americanos, 62: I (Jan.-June 2005), pp. 235-70; Stephan Ruderer, 'Cruzada contra el comunismo: tradición, familia y propiedad en la Argentina y Chile', Sociedad y Religión, 38 (2012), pp. 77-1 06.

${ }^{10}$ Margaret Power, Right-Wing Women in Chile: Feminine Power and the Struggle against Allende, 1964-1973 (University Park, PA: Penn State University Press, 2002); Sandra McGee 
and - at critical junctures - the dominant media, women's groups were the bases of a bloc cemented around conservative Catholicism. In the terms of cultural critic Raymond Williams, this bloc configured a 'residual force': much of its members' ideas and practices had been shaped in the past, but were 'active in the present'. ${ }^{11}$ As a bloc, it updated a resilient interpretation that viewed the spread of 'liberal' cultural practices, from psychoanalysis to unsupervised socialising among young people, as a stepping stone for the spread of communism. In the I 960 s and I 970 s that interpretation crystallised in cultural, educational and sexual policies, no matter whether the governments were civilian or military.

Through the lens of its main brainchild, the figure of the 'enemy within', this article studies the unfolding of that conservative bloc and the ways in which it engaged in a long-lasting politico-cultural struggle. With the exception of those who have studied the right-wing nationalists, scholars of I 960 S and 1970s Argentina have left the pervasiveness of that bloc largely unexplored. Interested in the spiralling interplay between repressive state policies and radicalising groups, scholars have also privileged attention to one or the other of the two decades. Hence, historians of the 1960 s have tended to show a civil society pushing for change that faced 'top-down', traditionalist blockades. This interpretation leaves scant room for noticing that some of the 'traditionalist' discourses, practices and institutions sprang from civil society and that they acquired new meanings when confronting the quests for cultural and political change which epitomised the 1960s. For their part, some historians of the I970s, while exploring representations of the 'enemy within', noted continuities with the 1960 s regarding anti-communist legislation, yet they did not look at the gendered, sexual and generational components of that picture. $^{12}$ All those elements were crucial to the ways in which conservative actors delineated the 'enemy within', represented as defiant towards the

Deutsch, 'Christians, Homemakers, and Transgressors: Extreme Right-Wing Women in Twentieth-Century Brazil', Journal of Women's History, 16: 3 (2004), pp. I 23-37; Soledad Loaeza, 'Mexico in the Fifties: Women and Church in Holy Alliance', Women's Studies Quarterly, 33: 3-4 (2005), pp. I38-60.

I Raymond Williams, Marxism and Literature (New York: Oxford University Press, 1977), p. I 22.

12 Guillermo O'Donnell, Bureaucratic Authoritarianism: Argentina, 1966-1973 (Berkeley, CA: University of California Press, 1988); Liliana De Riz, La politica en suspenso, 1966-1976 (Buenos Aires: Paidós, 200 I); Carlos Altamirano, Bajo el signo de las masas (1943-1973) (Buenos Aires: Ariel, 200I). On the 'traditionalist blockade', see Oscar Terán, Nuestros años sesenta: la formación de una izquierda intelectual en la Argentina (Buenos Aires: Puntosur, I99 I); and Sergio Pujol, La década rebelde: los sesenta en la Argentina (Buenos Aires: Emecé, 2000). On the ideas of 'enemy within' in the 1970s, see Marina Franco, Un enemigo para la nación: orden interno, violencia y 'subversión', 1973-1976 (Buenos Aires: Fondo de Cultura Económica, 2012), pp. 240-7I. 
political, socio-economic, cultural and sexual orders alike. In this respect, it was the figure of the 'guerrilla woman' that, by the early i 970 s, best embodied the conservative bloc's fears. The focus on that bloc will likewise serve to add to the new cultural histories of the Latin American Cold War. In particular, this essay contributes to approaches that analyse anti-communism and authoritarianism by looking at how civilian actors engaged with those projects. ${ }^{3}$ I contend that authoritarianism and cultural conservatism, rather than being a state prerogative, permeated Argentine society and set limits to the development of change in its interrelated cultural, political and sexual meanings.

The history of that politico-cultural struggle, which had the 'enemy within' as one of its central themes, is divided into three periods. From the late $1950 \mathrm{~s}$ to the mid-I960s, in the dynamics of political ascendancy in Argentine political life, the Catholic hierarchy and family organisations, along with military ideologues and right-wing politicians, re-created a vision associating 'liberalism' with communism. Although their voices appeared outmoded in a milieu saturated with debate and claims of cultural and political change, these conservative groups won decisive battles: they were influential in generating educational policy and building new legislation and apparatuses of censorship. They endorsed the military project that imposed the so-called Revolución Argentina (1966-73). Marked by the vicissitudes of this military regime, the second period brought mixed results: after the enactment of repressive cultural and sexual policies and the closure of political space, the Revolución Argentina unintentionally set the stage for a broader politicisation and radicalisation. As if it were a self-fulfilling prophecy, by the late i 960 s droves of young people became engaged with revolutionary projects, which they helped to carve out through their participation in student, party and guerrilla groups. That movement reached its peak in 1973, when the third Peronist government represented, for many, the closest approach to a national and social liberation. In that brief but intense conjuncture, the conservative bloc was on the defensive. However, it soon encountered fertile soil in a backlash originating within right-wing Peronism. Beginning in 1974 , the third period was punctuated by the spread of a perceived link between political, gender and sexual 'subversion', along with a project geared towards reconstituting political and cultural 'order' - a project which the military junta established in March 1976 promised to accomplish.

${ }^{13}$ Gilbert Joseph, 'What We Know and What We Should Know: Bringing Latin America More Meaningfully into Cold War Studies', in Gilbert Joseph and Daniela Spenser (eds.), In from the Cold: Latin America's New Encounter with the Cold War (Durham, NC: Duke University Press, 2008), pp. 19, 24-5. 


\section{Imagining the 'Enemy Within'}

The Catholic Church was crucial in creating a framework for imagining the 'enemy within', together with the means for struggling against it: the upholding of 'society's basic cell', the family. In his 1930 encyclical, Casti Connubii, Pope Pius XI felt compelled to remind his flock that the family, conceived as God-created, entailed 'the primacy of the husband with regard to the wife and children, and the subjection of the wife and her willing obedience'. ${ }^{14}$ Positing the defence of the patriarchal family as the antidote against 'modern-time evils' (including women's greater autonomy and the expansion of mass culture), Casti Connubii oriented the activities and beliefs of the Argentine Catholic community as well. Revitalised in the r930s through organisations such as Catholic Action, that community challenged the secularist traditions of Argentina's culture. The project of reCatholicisation gained thousands of militants, chiefly among the middle classes, and aimed to forge a 'Christian nation' around the family. ${ }^{15}$

In the immediate post-war period, the re-Catholicisation project acquired new meanings when it intersected at the international level with the intensified anti-communism emanating from the Vatican and at the national level with the vicissitudes in the relationship between the Catholic Church and Peronism. The Vatican waged its own Cold War, which considered the politics of containment developed by Washington insufficient and called for a crusade against 'atheistic Communism' in the West and East alike. ${ }^{16}$ In 1949, the Vatican issued an ecumenical warning to Catholics, stating that those in any way favouring 'materialist, antichristian doctrines were ipso facto apostates and incurred excommunication'. ${ }^{17}$ Only the defence of the 'Christian family', the letter posited, could prevent communism from spreading. In those years, the Peronist governments (1946-55) endorsed anti-communist policies, together with 'pro-family' initiatives that, for example, favoured the retreat of married women from paid labour and encouraged increasing fertility rates. ${ }^{18}$ In both respects, Catholics sided with

${ }^{14}$ Pius XI, 'Casti Connubii', in Anne Fremantle (ed.), The Papal Encyclicals in their Historical Context (New York: New American Library, 1963), pp. 299-300.

is Loris Zanatta, Del estado liberal a la nación católica (Bernal: Universidad Nacional de Quilmes, 1999); omar acha, “'Organicemos la contrarrevolución”: discursos católicos sobre los géneros, la familia y la reproducción a través de Criterio (1928-1943)', in Paula Halperin and omar acha (eds.), Cuerpos, géneros, identidades: estudios de historia de género en la Argentina (Buenos Aires: del Signo, 2000), pp. 135-93.

${ }^{16}$ Michael Phayer, Pius XII, the Holocaust, and the Cold War (Bloomington, IN: Indiana University Press, 2008).

${ }^{17}$ See Elisa Carrillo, 'The Italian Catholic Church and Communism, 1943-63', Catholic Historical Review, 77: 4 (1991), p. 650.

${ }^{18}$ Isabella Cosse, Estigmas de nacimiento: peronismo y orden familiar, 1945-55 (Buenos Aires: Fondo de Cultura Económica and Universidad de San Andrés, 2006). 
the government. Initially, they also benefited from the incorporation of religious education into the curriculum of primary schools and from state funding of an expanding network of parishes. The relationship between Peronism and the Catholic community, however, turned into an embattled arena, as scholars have shown, as the Peronist elites developed their politicoliturgical practices along with their own, anticlerical, interpretation of Christianity, which posited the state as the arbiter of who was the authentic Christian and why. ${ }^{19}$ This shift came at a time of increasing polarisation of the political field, and the Church moved to the side of the opposition. In that context, in late 1954 Congress passed the laws of divorce and of 'equalising rights' to children born out of wedlock. ${ }^{20}$ In a mounting political crisis, Catholic organisations, along with all political parties, were protagonists of the coup d'état that overthrew Perón in I 955 and sent him into exile, initiating I 8 years when civilian and military rule alternated and the most popular political force, Peronism, was banned.

The legitimacy that the Catholic Church gained in its opposition to Peronism helps explain its cultural and political ascendancy in Argentina's public life, a dynamics in which the family organisations formed by men and, chiefly, women of the laity gained a major role. By the early I950s, the project of re-Catholicisation seemed stagnant, as membership of three of the four branches of Catholic Action (young men, young women and adult men) had begun to decline steadily. The exception was the participation of adult women. In $195 \mathrm{I}$, in the context of a reorganisation of laypeople along the lines of the 'environmental apostolate' (apostolado ambiental) - that is, the family, workplace and community environment in which Catholic militants carried out their activities as disciples - the hierarchy promoted the creation of the Liga de Madres de Familia (League of Mothers). ${ }^{21}$ Women were called upon to develop their 'apostolate' in the milieu where they supposedly belonged, the family, and in the role that they were deemed to fulfil, that of mothers. The primary goal of the League was to 'protect' the family, which they thought of as threatened by broad socio-cultural forces, such as the incorporation of women into the extra-domestic labour force, the effects of the media, and the concomitant decrease of patriarchal authority. Membership was restricted to religiously married women, and single mothers were explicitly banned from

19 Lila Caimari, Perón y la Iglesia Católica: religión, estado y sociedad en la Argentina, 1943-1955 (Buenos Aires: Ariel, 1995); Mariano Plotkin, Mañana es San Perón: propaganda, rituales politicos y educación en el régimen peronista, 1946-1955 (Buenos Aires: Ariel, 1994).

20 Susana Bianchi, Catolicismo y peronismo: religión y politica en la Argentina, 1943-1955 (Tandil: Instituto de Estudios Históricos, 2001), pp. 1 49-67, 291-3 17; Caimari, Perón y la Iglesia Católica, pp. 292-3 10; Cosse, Estigmas de nacimiento.

${ }^{21}$ See omar acha, 'Notas sobre la evolución cuantitativa de la afiliación en la Acción Católica Argentina (193 I-1960)', documento de trabajo, available at www.historiapolitica.com. 
participating. ${ }^{22}$ The League's leaders had upper-class origins, and some of them had been active participants in charity groups. However, the League expressly wanted to depart from any connection with charity and to expand the Catholic women's network so as to incorporate members from the middle classes. It was quite successful in this: by the early 1960s, the League had branches in 25 out of 35 ecclesiastical circumscriptions and, according to its own statistics, its membership had reached 80,000 women. ${ }^{23}$ The achievement in recruitment was linked to the two main activities the League pursued. On the one hand, it carried out initiatives geared to the 'social protection' of the family, including the running of food and clothing stores as well as some children's day-care centres to which members alone had access. On the other hand, the League undertook a series of politico-cultural endeavours that positioned it as one of the most visible moral watchdog organisations of 1960 s and r970s Argentina and as a key actor within the emerging conservative bloc.

The League of Mothers was at the centre of a myriad of initiatives to 'protect the family' against what Catholic groups viewed as the concomitant forces of 'liberalism' and 'communism'. In 1957, for example, the League of Mothers, the League of Fathers, and the Christian Family Movement fuelled the creation of a Family Front. In a mass rally in front of the Congress building, the Front's leaders loudly advocated the 'indissolubility of marriage', the 'defence of a strong paternal authority' and the vindication of 'a caring, homemaking woman'. They requested Congress to discontinue the divorce law and to pass more severe penalties for adultery and abortion. ${ }^{24}$ In addition, in 1960 all the organisations within the Front were founding members of OASMO. Its president was a lawyer, Manuel Fasano, who, using the terminology of Stanley Cohen, was a 'moral entrepreneur': he occupied positions on censorship boards and built up his political career by publicising concerns surrounding the 'the liberalisation of morals and customs', which he viewed as the first step towards any 'subversion'. ${ }^{25}$ A promoter of conferences such as the one held in 196I which I mentioned at the beginning of this essay, he joined forces with other prominent Catholic figures. A priest, Manuel Moledo, counsellor to the League of Mothers, for example, lectured tirelessly at schools and union headquarters, as well as on radio and television in the free

22 Bianchi, Catolicismo y peronismo, pp. I64-6; Lila Vázquez Lorda, 'Intervenciones e iniciativas católicas en el ámbito familiar: las Ligas de Madres y Padres de Familia (Argentina, 1950I 970)', unpubl. Master's thesis, Universidad de San Andrés, 20 I 2.

${ }^{23}$ Organización y propósitos, 1962, Comité Central file, Liga de Madres de Familia Archive (LMF Archive).

24 'Clausuróse el Congreso de la Familia', Boletín AICA, 66, 9 Sep. 1957, pp. 6-7.

25 'Proyecto sobre moralidad', OASMO Informa, I (1960), pp. 5-6; on the concept of the 'moral entrepreneur', see Stanley Cohen, Folk Devils and Moral Panics: The Creation of the Mods and the Rockers (London: Routledge, 2002), p. 217. 
programming time that the League obtained. ${ }^{26} \mathrm{He}$ explained that the League's actions were first and foremost intended to defend the moral well-being of youth. Young people, he stated, lived in troubled homes, where 'even mothers dared to criticise the father in front of them'. Youths thus launched themselves into adult life ill-equipped to see what 'our present day shows', a list that included 'sensualist music, literature and movies'. That environment, in his view, was both the cause and effect of the hedonism and materialism associated with 'atheistic liberalism', the first step in the weakening of morals that made the terrain ripe for 'communist infiltration'. ${ }^{27}$

The conservative Catholic groups waged a Janus-headed war on liberalism (in its political and cultural meanings) and what they viewed as its continuation, communism. As historians have shown for the early twentieth century, Catholic and nationalist intellectuals had long established that connection, and they went as far as to blame the egalitarian and allegedly disorderly elements of democracy and mass politics for facilitating the conditions for the spread of liberalism and 'maximalism' or communism. ${ }^{28}$ Those fears intensified in the 1960 s as a result of both the emergence of new cultural patterns associated with youth and, chiefly, the echoes of the Cuban Revolution. In 1960, one of the first opinion-survey companies in the country, led by a prominent Catholic sociologist, José Míguez, conducted a poll to verify the 'psychological characteristics' that would make Argentines attracted to communism. The survey incorporated two peculiar questions: first, it asked interviewees whether or not they agreed that 'a young woman can go out at night without parental permission' - 90 per cent disagreed - and, second, whether or not they concurred with the assertion that 'military service had positive effects on young men' - 80 per cent concurred. In explaining the rationale of both questions, the researchers argued that they served to assess 'the penetration of liberal ideas', which eroded 'the basis of the patriarchal family and the principle of authority'. Notwithstanding the results, the conclusion indicated that those ideas had begun to find room 'among the middle-classes and the youngest groups'. ${ }^{29}$ In the year that followed, when asking about attitudes towards the Cuban process, they found that 'the population in the $18-25$ age group and the middle classes' was inclined to support it. ${ }^{30}$ At the centre of the 'liberalism' that jeopardised family authority

${ }^{26}$ Actas de Escuela para Padres, 2 and 3, 14 May and 29 Aug. 1964, Escuela para Padres file, LMF Archive.

27 ‘Qué pasa con la juventud?’, La Razón, i 8 July i 959, p. 7; 'Academia de amor', La Razón, i I Nov. 1959, p. I I; 'Dimensión de la juventud de hoy', Nuestros Hijos, 59 (Dec. 1959), pp. 13-15.

${ }_{28}$ McGee Deutsch, Las Derechas; Zanatta, Del estado liberal a la nación católica.

29 Cuarta Encuesta Nacional de Opinión Pública, Aug. 1960, Colección José Enrique Miguens, Colecciones Especiales y Archivos, Biblioteca Max von Buch, Universidad de San Andrés.

${ }^{30}$ Quinta Encuesta Nacional de Opinión Pública, May I 96 I, Colección José Enrique Miguens. 
and challenged the principles of authority, the researchers claimed, middleclass educated youth was the main target.

Youth was at the centre of the concerns shared by Catholic groups, military ideologues and right-wing politicians. Like many of their Latin American counterparts, these actors advocated making the educational and cultural milieus anti-communist bastions. ${ }^{31}$ Among the military, both French and North American influences nurtured the belief that an unconventional war was under way. In that war, the military was called to defend the ideological frontiers of the 'west' from an enemy thought of as already within the nation and acting on multiple fronts (political, ideological, cultural).32 When it came to the educational and cultural 'fronts', the military drew on conservative Catholic ideas. Writing for the quarterly journal of the Círculo Militar, an influential forum for the ideological formation of military personnel, Colonel Rómulo Menéndez indicated that as 'infiltrated' agents in schools, 'the communists want to break up the family - through divorce, ideas on communication among its members, and the breakdown of the father's authority'. ${ }^{33}$ Also concerned with controlling the school system, the Episcopal Committee denounced, for example, the fact that principals of secondary schools had hired psychologists to discuss their school, family and sexual problems with female students. To the Committee, these initiatives eroded family authority and were 'communist by nature'. ${ }^{4} 4$ A report sent to Frondizi's minister of education reproduced similar ideas, and concluded that 'the girls will end up by questioning their role as students, daughters, mothers: communist dissociation'.35 A Catholic minister, Luis McKay, discontinued the 'psychological experiences' entirely.

This example shows succinctly that conservative Catholic groups thoroughly defended a status quo based on clear-cut gender divides within a strictly patriarchal family structure. From this standpoint, they reinforced their activism to confront other political or cultural actors, such as psychological professionals. As Mariano Plotkin has noted, as a 'scientific and progressive'

${ }^{31}$ See Benjamin Cowan, “Why Hasn't this Teacher Been Shot?” Moral-Sexual Panic, the Repressive Right, and Brazil's National Security State', Hispanic American Historical Review, 92: 3 (2012), pp. 403-36.

32 Alain Rouquié, Poder militar y sociedad politica en la Argentina, vol. 2 (Buenos Aires: Emecé, I991); Daniel Mazzei, 'La misión militar francesa en la Escuela Superior de Guerra y los orígenes de la Guerra Sucia, 1957-196r', Revista de Ciencias Sociales, 13 (Dec. 2002), pp. $105-37$.

33 Coronel Rómulo Menendez, 'Las Fuerzas Armadas y la defensa nacional', Revista Militar, 660 (1961), pp. I3-17.

34 'En la Escuela Normal No. 4', Boletín AICA, 176, 23 Oct. 1959, p. 2; 'Comunismo en la educación: Liceo 3', Boletín AICA, 178, 3 Nov. 1959, p. 4.

35 Informe del estado actual de la Facultad de Filosofía y Letras relacionado con la Escuela Normal No. 4, box 817, Archivo Arturo Frondizi, Biblioteca Nacional Argentina - Archivos y Colecciones Particulares. 
discourse that spread among the middle classes during the I960s, psychoanalysis did not challenge entrenched values relating to gender inequality and compulsory heterosexuality, but it did allow for negotiating change in the intimate and cultural milieus. ${ }^{36}$ The psychological professionals gained growing legitimacy, creating influential discourses and practices that ideally tended towards the democratisation of family life, including new patterns of child-rearing and the granting of greater autonomies to young people. The conservative Catholic groups could not compete with the psychological professionals' media and cultural accomplishments, as these came to epitomise novelty and modernisation. ${ }^{37}$ However, as if a symbolic exchange were taking place, they influenced policy-making in the realms of education - such as the blockade of the psychological experiences at secondary schools - and, more broadly, of culture.

The conservative Catholic groups helped set some of the cultural conditions in which the I960s unfolded in Argentina. In contrast to (for instance) England or Germany, Argentina did not have a 'permissive moment' that made the representation and practice of sexuality more flexible, including the discontinuation of the legal category of 'obscenity', the fundamental decriminalisation of homosexuality and the granting of abortion rights. ${ }^{38}$ In Argentina, abortion was and still is illegal, and anti-communist legislation paving the way for detentions in order to check criminal records - passed in I 958 and 1965 - informed the persistent persecution to which homosexuals were subjected. 39 In addition, as the I960s went on, censorship did not relax but was reinforced to blockade the diffusion of 'politically subversive' and 'morally harmful' materials alike. Either independently or through their representatives in state institutions such as the Consejo Nacional de Protección de Menores (National Council for the Protection of Minors), the Catholic family organisations participated in censorship boards and exerted pressure on district attorneys or judges to prosecute those who allegedly violated Article 128 of the Penal Code prohibiting the diffusion of 'obscene' materials. ${ }^{\circ \circ}$ Together with pornography and magazines with semi-nudes in their illustrations, the list of censored works included Vladimir Nabokov's

${ }^{36}$ Mariano Plotkin, Freud in the Pampas: Origins and Development of a Psychoanalytical Culture in Argentina (Stanford, CA: Stanford University Press, 200 I), pp. 84-5.

37 Isabella Cosse, Pareja, sexualidad y familia en los años sesenta (Buenos Aires: Siglo XXI, 2010).

${ }^{38}$ Marcus Collins, Modern Love: An Intimate History of Men and Women in TwentiethCentury England (London: Atlantic Books, 2003), pp. 134-60; Dagmar Herzog, Sex after Fascism: Memory and Morality in Twentieth-Century Germany (Princeton, NJ: Princeton University Press, 2005), pp. 1 53-60.

39 Carlos Jáuregui, La homosexualidad en la Argentina (Buenos Aires: Tarso, 1987), pp. 163-7.

40 'Se pide una medida nacional contra las publicaciones inmorales', Boletín AICA, 99, 25 May 1958, p. 3; 'Manifiesto JAC', Boletín AICA, i 89, i Jan. 1960, pp. 8-9. 
Lolita in 1957 and Henry Miller's Nexus in 1964, and some two dozen writers and publishers were prosecuted. ${ }^{41}$

While conservative Catholics worked within already existing legal frameworks in the case of print materials, they also helped create new apparatuses and legislation regarding the censorship of visual media. With respect to television, in 1965 they won a major battle with the passing of a presidential decree mandating that television programmes that showed 'the dissolution of the family, sexual deviancy and eroticism' would be discontinued. ${ }^{22}$ The story was similar regarding cinema. In 1959, Catholic family organisations were active proponents of the creation of a Board of Film Qualification, where their representatives comprised ten of the 19 members, mandating harsh decisions throughout. In September 1963, moreover, the de facto government of José M. Guido $(1962-3)$ issued a decree authorising the Board to cut movies that affected 'national security, threatened by the ideological infiltration that weakens the internal front through the corruption of morals, the scorning of tradition, the dislocation of the family and the relenting of spiritual values'. ${ }^{43}$ The Board epitomised the conservatism and authoritarianism permeating the Argentine 1960s, yet those attributes were as crucial as the yearning for change and cultural renovation in the definition of that 'era' and its possibilities.

In that process, conservative Catholic groups contributed to delineating the gendered and sexual ramifications of the 'enemy within' and to popularising an imagery that associated youth, weakening morals and chaos with the communist threat. In the I960s, many Argentines viewed the Catholic-based project as atavistic. Ideally, those remnants of the old Argentina would vanish in a modernising dynamic fuelled, for example, by rising enrolments in secondary schools and universities or the cosmopolitanism of cultural life. Perhaps this confidence helps explain why the institutionalisation of censorship met with so little opposition. Yet the Catholic groups only heightened the anxieties and fears of broader segments of society about the cultural and sexual changes embodied, mainly, in youth. ${ }^{44}$ These groups, like many Argentines, initially welcomed a project that promised to reconstitute order and authority in all social relations and to erode the 'conditions for

${ }^{41}$ For a retrospective account, see 'Los que ofenden al sexo', Análisis, 427, 20 May 1969, pp. 23-6.

42 'Reglamentación del decreto ley I 5460/57', La Nación, 17 Nov. 1965, p. 2.

43 'Decreto 8205', Boletín Oficial, 3 Oct. 1963, p. 3. See Andrés Avellaneda, Censura, autoritarismo y cultura en la Argentina, 1960-1983, vol. I (Buenos Aires: CEAL, 1986), esp. pp. $40-3$.

44 Valeria Manzano, 'Sexualizing Youth: Morality Campaigns and Representations of Youth in Early i960s Buenos Aires', Journal of the History of Sexuality, I4: 3 (2005), pp. 43 I-6I. 
a subtle but aggressive Marxist penetration', as stated in the initial manifesto issued by the military that imposed the Revolución Argentina.45

\section{A Self-Fulfilling Prophecy}

Led by General Juan Carlos Onganía (1966-70), the Revolución Argentina represented what Guillermo O'Donnell termed a bureaucratic-authoritarian regime. Committed to a project of socio-economic planning and strong anticommunism, the regime announced that it had goals, but not specific time frames to accomplish them. Aligned with Robert McNamara's precepts for national security, the military's first objective was to produce the conditions to 'economically develop' the country. To that end, the regime aimed to deactivate popular mobilisation, and it also suppressed Congress, outlawed all political parties and set limits to the functioning of the trade unions. ${ }^{46}$ As he had already posited in his 1964 speech before the United States Military Academy at West Point, Onganía insisted on recrafting the role of the armed forces, which were called on 'to preserve the moral and spiritual values of western and Christian civilisation'. ${ }^{47}$ The conservative Catholic groups endorsed the regime and the League of Fathers went as far as to create a proposal for a Ministry of the Family - which turned into a poorly funded undersecretariat. ${ }^{8}$ These groups also supported the most controversial measures that the regime undertook.

A month after its imposition, the Onganía regime carried out two initiatives that touched, in particular, upon young people's lives. On 29 July i 966 , the military intervened in the autonomous universities, which, according to the principles articulated by the University Reform movement of 1918, had a tripartite government composed of professors, alumni and students. The military decision was based upon a belief shared by both the conservative Catholic groups and the armed forces. As one colonel in 1962 reminded his readers, the tripartite form of government entailed 'the total subversion of hierarchies' and paved the way for the further politicisation of the universities, where 'communism ended up by shaping the future leading class's mentality.' ${ }^{49}$

45 'Acta de la Revolución Argentina, 28 de junio de 1966', in Gregorio Selser, El Onganiato (I): la espada y el hisopo (Buenos Aires: Hyspamérica, 1986), p. 323.

${ }^{46}$ O'Donnell, Bureaucratic Authoritarianism, pp. I 5-83.

${ }^{47}$ Rouquié, Poder militar y sociedad politica, vol. 2, pp. 231, 259-60; Paul H. Lewis, 'The Right and Military Rule, 1955-1983', in Sandra McGee Deutsch and Ronald H. Dolkart (eds.), The Argentine Right: Its History and Intellectual Origins, IgIo to the Present (Wilmington, DE: Scholarly Resources, I 993), pp. I 55-6.

48 'La Liga de Padres pone en consideración un ministerio de la familia', Boletín AICA, 5 I6, 26 July i 966 , p. I.

49 Col Horacio Quero, 'Acción comunista en el campo educacional', Revista Militar, 663 (1962), pp. 59-69. 
Besides passing a decree for the intervention, the government authorised the police to enter three schools at the University of Buenos Aires (UBA), where they beat and arrested 300 students and professors. The 'night of the long sticks', as it was called, showed that the military would use violence to safeguard 'order', for the sake of which they also banned the student federations. ${ }^{50}$ In the same weeks, invoking a common conservative Catholic theme, the mayor of Buenos Aires argued that communism acted through the 'subversion of sexual mores', and asked the police to launch a morality campaign that included raids on nightclubs, plazas and per-hour hotels where young people supposedly engaged in premarital sex. One particular strand involved police persecution of young men who wore long hair and bright-coloured clothes, usually as a feature of rock culture. After shaving the heads of 20 of them, a police officer asserted that their use of 'unisex' fashion was an issue of national security because it prevented the police forces from distinguishing men from women. ${ }^{5}{ }^{5}$

These initiatives, which sought to set limits on the supposed communist penetration into the ranks of young people, had totally unintended consequences. Intense as they were, the repressive measures encapsulated in the morality campaigns did not prevent rock culture from emerging. Moreover, these endeavours reshaped the meanings of the cultural practices of Argentina's rock culture, which acted as a site for the learning and deployment of anti-authoritarianism. Similarly, the use of violence against students and professors contributed to the erosion of the regime's initial legitimacy, especially since $\mathrm{I}, 200$ professors resigned because they refused to work under military supervision. An opinion survey showed that support for the regime among the middle classes had decreased from 60 per cent in July 1966 to 42 per cent in March 1967, partly due to their attitudes towards the intervention..$^{52}$ Interestingly, the League of Mothers voiced its concerns regarding the university situation. Commemorating the first anniversary of the military regime, the League congratulated the government for its decision to 'deter chaos' from the university classrooms, but at the same time they demanded more 'pluralism and excellence' in the teaching options. ${ }^{53}$ These mixed feelings shown by the League vis-à-vis the Onganía regime signalled a repositioning of the Catholic groups in the second half of the 1960 .

As in most Latin American countries, the Catholic community in Argentina felt the effects of the Second Vatican Council (1962-5) deeply.

so Sergio Morero, Ariel Eidelman and Guido Litchman, La noche de los bastones largos (Buenos Aires: GEL, 1999).

${ }^{51}$ Valeria Manzano, 'Rock Nacional, Revolutionary Politics, and the Making of a Youth Culture of Contestation in Argentina, 1966-1976', The Americas, 70: 3 (2014), pp. 393-427.

52 Encuesta de opinion pública no. I0, March 1967, Colección José Enrique Miguens.

53 'El gobierno, triunfos y tentaciones', Vivir en Familia, 47 (May 1967). 
The discussions set in motion during the Council, chiefly those related to the Church's privileged 'option for the poor', provided the framework for new ways of activism. Beginning in 1966, groups of students in Córdoba, Rosario and Buenos Aires began to meet in parishes to discuss the Council's documents and conduct social work in slums. ${ }^{54}$ Prioritising the social component of Catholic activism, even the League of Mothers vindicated, for example, the experience of the Campamentos Universitarios de Trabajo (University Social Work Camps, CUTS), through which 2,000 students went out to the most impoverished provinces to share the labourers' daily work and to teach the Gospel to children.55 However, neither the League nor other conservative Catholic groups approved of the most radicalised interpretations of the Council's teachings, including those coming from a new cohort of university students. By mid-1968, most Catholic students had joined the Unión Nacional de Estudiantes (National Students' Union, UNE), which claimed that the only criterion for membership was 'to be a revolutionary: to be a student is an anecdote'. The UNE claimed that the military intervention in the university had had positive effects, since it had pushed the students towards their encounter with the 'proscribed people', in a reference to Peronism. ${ }^{56}$ In that encounter, they also met students coming from a Marxist background, who in 1968 converged around the Federación de Estudiantes Nacionales (Federation of National Students, FEN), and came to envisage Peronism as a setting in which to build a 'national road' towards socialism and social liberation.

The students and other radicalised actors opposed conservative Catholicism and the Onganía regime on the basis of political and social premises, leaving their sexual politics untouched. In order to prevent what they conceived of as 'hedonistic' attitudes from spreading among its ranks, the most important groups of the revolutionary Left emerging in the second half of the i960s came to share the 'anti-liberal' stance promoted at the other side of the political spectrum. In 1968, for example, one of the most significant forums for registering the voices of the student and labour activists, the journal Cristianismo y Revolución, chose to ask a Peronist priest to comment on Paul VI's encyclical Humanae Vitae, which endorsed periodic abstinence as the only method for 'family planning' and condemned the contraceptive pill. Anticipating a view that would become common in leftist quarters, the priest argued that in Latin America only 'superfluous young women' were on the pill. Like many others at the time, he conceived of the pill as a tool through which 'Yankee imperialism' tried to avoid population growth

\footnotetext{
54 'Córdoba: Manifiesto Universitario', Cristianismo y Revolución, 2-3 (Nov. 1966), pp. 7-8.

s5 'Asomarse a las provincias', Vivir en Familia, 62 (Nov. 1968).

56 'Los estudiantes y el nuevo evangelio de la violencia', Panorama, 68, I 3 Aug. 1968, p. I 4.
} 
in the third world. 57 Likewise, as happened with the Brazilian and Mexican Left, both the Peronist and the Marxist revolutionary groups argued that only the monogamous, heterosexual couple could balance the hedonism of their members and consequently condemned any attempt at sexual experimentation. ${ }^{8}{ }^{8}$ It is not surprising, then, that in the context of the global upheavals of 1968 many Argentine student leaders rejected Herbert Marcuse's ideas about the potentials of 'unleashing Eros' to attain a political, while sexual, revolution. 'If his theses work for Europe, they do not for us', one student argued. The UNE's leader was more emphatic: 'Marcuse can go to hell.' Like others, he predicted that, in Argentina, 'things will be different'. 59

In some respects, 'things were different'. In May 1969, a series of popular revolts erupted in Corrientes, Rosario and Córdoba in which students were leading forces, alongside workers and broad segments of the local populations. Although articulated around economic and social demands, the unifying thread of the Argentine May was political. The intensity and scope of the revolts signalled a deep-seated discontent with a political order that had excluded, since 1955, the representation of the majority forces and that, since 1966, had closed all channels for politics. ${ }^{60}$ At the level of the regime, the popular revolts prompted the beginning of the end of the Revolución Argentina: everyone in the Cabinet resigned, although Onganía did not do so until June 1970, when the Peronist guerrillas, the Montoneros (whose ideological and political origins dated back to political radicalisation in Catholic milieus), kidnapped and killed a former president, Pedro Eugenio Aramburu. This detail is significant because it speaks concisely of the renewed dynamics of Argentine politics. The surfacing of five major guerrilla groups was coupled with a broad and ever more radical politicisation of society. In that process, rising numbers of young people engaged with projects aimed at forging a socialist future (either in its classless Marxist, or in its national,

57 Hernán Benítez, 'La Humanae Vitae: un golpe al imperialismo y a la oligarquía', Cristianismo y Revolución, 9 (Sep. 1968), pp. $2-7$.

58 See Manzano, The Age of Youth in Argentina, pp. 202-19. For comparisons with other Latin American experiences, see James Green, "Who Is the Macho Who Wants to Kill Me?" Male Homosexuality, Revolutionary Masculinity, and the Brazilian Armed Struggle of the r 960 s and I970', Hispanic American Historical Review, 92: 3 (2012), pp. 437-69; and Eric Zolov, 'Expanding Our Conceptual Horizons: The Shift from an Old to a New Left in Latin America', A Contracorriente, 5: 2 (2008), pp. 47-72.

59 'Marcuse, el nuevo profeta de la izquierda', Panorama, 73, 17 Sep. 1968, p. 82; 'Hablan los dirigentes estudiantiles', Semanario CGT, 33, I 2 Dec. 1968, p. 3.

${ }^{60}$ See James Brennan, The Labor Wars in Cordoba, 1955-1976: Work, Ideology, and Labor Politics in an Argentine Industrial City (Cambridge, MA: Harvard University Press, 1994), esp. chap. 5 . 
Peronist version), a movement which reached its peak between I 970 and $1973 .^{61}$

For the conservative Catholic groups and the ideologues within the armed forces, the tide of political radicalisation was a self-fulfilling prophecy. While in the I 960 s far-right Catholic intellectuals such as Jordán Bruno Genta and Julio Meinville participated in the formation of military cadres, now some Catholic groups requested the military's expertise in order to learn about new ways of political activism. In I970, for example, the Universidad Católica de Buenos Aires organised widely publicised lectures to address youth politicisation. The series began with a lecture by General Tomás Sánchez de Anchorena, where - ironically - he discussed how the spread of Marcuse's 'erotic and post-materialistic philosophy' had reversed the moral principles through which the youth had been raised. Crystallised in new sexual mores, those ideas 'subverted everything', another panellist concluded. ${ }^{62}$ Taking up the same ideas, the army organised its I97 I course for lower-level cadres and conscripts. Five out of eleven lessons focused on how liberalism and communism had acted in tandem to erase the fabric of the nation. As an example, the lessons highlighted the breakdown of the 'true' Catholic faith among youth, 'brainwashed by leftist priests' who encouraged them even to 'level the sexes' and forget what 'men's and women's duties are'.63 Similar anxieties surfaced in the air force's reports. In 1972, Brigadier José D'Odorico, a leading counterinsurgency expert trained in France and the United States, alerted his comrades to new recruitment tactics: "the "guerrillas" [a catchword covering all leftist militants] do not hesitate to use young women, who in turn do not hesitate to use their sexual charms to get recruits'. ${ }^{4}$ Young women, in his view, used a weapon that made them particularly dangerous, threatening the gender, sexual and political orders alike.

In the early i970s, newspapers and magazines were awash with stories of dangerous and alluring young women participating in armed actions. That representation was premised on a basic occurrence: women engaged with revolutionary groups enthusiastically. Although there are no exact figures, prudent estimates state that, in 1973 , women represented 25 per cent of the

${ }^{61}$ For a general overview, see Alfredo Pucciarelli (ed.), La primacia de la politica: Lanusse, Perón y la Nueva Izquierda en tiempos del GAN (Buenos Aires: EUdeBA, 1999). For the most important guerrilla groups, see Richard Gillespie, Soldiers of Perón: Argentina's Montoneros (New York: Clarendon Press, 1982); and Pablo Pozzi, Por las sendas argentinas: el PRT-ERP, la guerrilla marxista (Buenos Aires: EUdeBA, 200I).

62 'Radiografía de los Montoneros', La Razón, is Aug. 1970, p. 5; 'Argentina en la campaña subversiva', La Razón, i Oct. I 970, p. 9.

${ }_{63}$ Boletín de Educación e Instrucción del Ejército, 22 (1972), pp. I 29, I 3 I, I 55, I64-7.

${ }^{64}$ Comodoro José C. D'Odorico, 'Las guerrillas', Revista de la Escuela de Comando y Estado Mayor de la Fuerza Aérea Argentina, 64 (Aug. 1972), p. 63. 
membership of all the groups embracing armed struggle - a percentage between the estimated 20 per cent for I 960 S Brazil and 30 per cent for 1970s Nicaragua, one of the largest such percentages in Latin America. ${ }^{65}$ Although only a few of them made it to the military fronts of the revolutionary groups, the press made a point of reporting on young women with guns. Commercial strategies worked alongside political ones, since the participation of women allowed journalists to highlight the spectacular characteristics of guerrilla activities, addressing readers avid for detailed reports. In July I 970 , for example, the press told the story of a Montonero cell made up of eight young men and three women, who took over a small town in Córdoba. Besides emphasising that the guerrillas belonged to Córdoba's 'best families', the press pointed out that the women had begun the takeover: 'a beautiful Amazon with a 38 -calibre gun initiated everything. ${ }^{66}$ In the two years that followed, stories of 'young women who looked like fashion models', wearing miniskirts and lots of makeup, proliferated. Like Brigadier D'Odorico, the press showed sexualised young women using their charms to deceive their targets: policemen, soldiers or simple passers-by. ${ }^{67}$ Commenting on the case of four women who had run away from prison, a journalist wrote that 'women showed more audacity, danger and sang-froid than men in guerrilla activities: it is part of the unfolding revolution'. ${ }^{68}$

From the standpoint of the conservative Catholic groups, the armed forces and segments of the press, the panorama looked apocalyptic. The depictions of the 'guerrilla woman' served as a reminder of what had gone awry in the $1960 \mathrm{~s}$, resulting in eroticism, gender 'disorder' and violence. To confront this panorama, the League of Mothers' counsellor, the priest Moledo, updated his understanding of the role of the family in the moral formation of youth. In particular, he called on parents to 'truly listen' to what the youngest members of their family were expressing when they engaged in politics. Parents should welcome their children's interest in 'ameliorating social conditions', but they should be cautious about the 'means' their children chose to do so and should

${ }^{65}$ María José Moyano, Argentina's Lost Patrol: Armed Struggle, 1969-1979 (New Haven, CT: Yale University Press, 1995), p. I06; Karin Grammático, Mujeres montoneras: una historia de la Agrupación Evita, 1973-1974 (Buenos Aires: Luxemburg, 201 I), p. 50; Pozzi, Por las sendas argentinas, p. 70. For Nicaragua, see Karen Kampwirth, Women and Guerrilla Movements: Nicaragua, El Salvador, Chiapas, Cuba (University Park, PA: Penn State University Press, 2002); and for Brazil, Victoria Langland, 'Birth Control Pills and Molotov Cocktails: Reading Sex and Revolution in 1968 Brazil', in In from the Cold, pp. 308-49.

66 'Los detenidos en Córdoba son jóvenes de las mejores familias', La Razón, 2 July 1970, p. I; last quote from 'Agitación: las 48 horas que conmovieron al país', Panorama, 167, 7 July I970, pp. I0-I 4 .

${ }^{67}$ Among many examples, see 'Audaz golpe en Córdoba', La Razón, 28 April 1970, p. I 2, 'La célula de Mendoza', 28 Oct. I970, p. I 3; 'Un comando en La Plata', 2 Feb. 1971, p. 8; and 'Golpe en Turdera', i 8 May i 971, p. I 3.

68 'Son peligrosas extremistas las cuatro mujeres fugadas', La Razón, 27 June I97I, p. 9. 
'always condemn violence'.69 Amidst an intense debate in which the Movimiento Sacerdotes para el Tercer Mundo (Movement of Priests for the Third World), which comprised io per cent of the regular clergy in 1970, publicly voiced its approval of the most radical means to 'transform social reality', the League of Mothers sided with the Church's hierarchy in a conservative stance that favoured calls for imposing 'order' within the Catholic community and in the country at large. $7^{\circ}$ However, apocalypses were unleashed within this group as well. In 1971, the League lost part of its constituency after its Central Committee published a letter paying homage to the members of the armed forces who had died 'at the hands of terrorist violence'. Several groups abandoned the League, expressing their discontent at the 'partisan nature' of a letter that had not condemned 'all violence', including that carried out by the armed forces. ${ }^{71}$ Though this was extreme, the splintering constitutes yet another example of the generalised politicisation and radicalisation that swept across the country.

The tide of social radicalisation reached its peak in 1973. Amidst rising politicisation, Onganía's successors, notably General Alejandro Lanusse ( 197 I-3), negotiated the road towards a democratic transition with the exiled Juan Perón. The military called elections in March 1973, but imposed restrictions on Perón's candidacy. Perón's personal representative in the country, Héctor Cámpora, ran for the presidency with the support of the Montoneros and the growing Juventud Peronista (Peronist Youth). With Cámpora's victory, the promise of national and social liberation looked close to fulfilment. In May and June, all political prisoners were set free and at the same time thousands of people occupied public schools, universities and hospitals to begin the construction of 'popular power'. ${ }^{2}$ In addition, while the universities did not recover the autonomy they had lost in 1966, they were strongholds of the revolutionary groups. The educational authorities agreed to shelve all restrictions on admissions to the universities and to reimagine a new model of the secondary school.

69 'Jóvenes rebeldes, ¿por qué?', Vivir en Familia, 65 (March 1969); 'Argentina: la hora política', Vivir en Familia, 85 (April 1971).

70 'Una declaración', La Razón, 5 Aug. 1970, p. 3. On the Movement of Priests for the Third World, see Claudia Touris, 'Neo-integralismo, denuncia profética y Revolución en la trayectoria del Movimiento de Sacerdotes para el Tercer Mundo', Prismas, 9 (2005), pp. 229-39.

${ }_{71}$ 'Solicitada: por una navidad de paz', La Razón, 2 I Dec. I97 I, p. i I; see also 'A la Junta Central de la Liga de Madres de Nuestra Señora de la Misericordia, 23 Dec. 197I’, letters folder, LMF Archive.

${ }^{72}$ For descriptions of the democratic process in 1973, see Eduardo Anguita and Martín Caparrós, La voluntad: una historia de la militancia revolucionaria en la Argentina, vol. 2 (Buenos Aires: Norma, 1997). 
The educational field experienced deep transformations in 1973, which were aimed, ideally, at pushing back the authoritarianism rampant in the secondary schools, for example. The educational authorities stated that it was a student's right to participate in the school's decision-making process, crucial to fostering 'active, risk-taking, caring youths', and therefore granted the students the right to mobilise politically at school..$^{73}$ The authorities further recommended campaigning for 'building horizontal out of vertical relations' at the schools in order to 'deter authoritarianism'. They suggested organising conferences and debates with students, teachers and parents to 'ensure that dialogue and equality prevail in the relations between teachers and students, parents and children, men and women' ${ }^{74}$ The proposals proved intolerable for the groups committed to preserving gender and familial hierarchies: the League of Mothers, for example, recommended that its members boycott the creation of school committees and refrain from participating in the conferences. 75 According to one conservative Catholic weekly, these educational initiatives were as dangerous as weapons, as they would help expand the most 'subversive' cultural and gendered components of the moral formation of youth and thus 'kill what was left of any idea of order and authority'. ${ }^{76}$

In addition, and to the horror of the conservative Catholic groups, in I 973 the government made inroads into the dismantling of censorship apparatuses and other pieces of legislation deemed culturally authoritarian. As soon as Cámpora was sworn in, he appointed a renowned Peronist filmmaker, Octavio Getino, to refashion the Catholic-dominated Board of Film Qualification. Whereas most of his ventures did not materialise, he did authorise the release of movies that had been previously prohibited, such as Pier Paolo Pasolini's Teorema (1 968) and Bernardo Bertolucci's Last Tango in Paris (1972). But the goal of promoting cultural openness took more everyday forms as well. Despite the opposition of the Catholic groups, the Ministry of Education authorised young women to attend secondary schools in trousers. 77 In a context of politico-cultural effervescence, conservative Catholics, like right-wing politicians, seemed defeated: their only chance was to boycott particular initiatives, yet their voices were marginalised not only in the media but also, most fundamentally, in the dynamics of decision-making related to the realms they valued the most, culture and education.

${ }^{73}$ La escuela media para la liberación y la reconstrucción nacional (Buenos Aires: Ministerio de Cultura y Educación, 1973), pp. 9, I3-16.

${ }^{74}$ Suplemento del Boletín de Comunicaciones del Ministerio de Cultura y Educación, I (July I973), pp. 4-7.

75 'La larga marcha hacia la liberación', Primera Plana, 5 1 o, 4 Oct. 1973.

76 'Cultura y metralletas', Esquiú, 699, i6 Sep. 1973, p. 5; see also 'Dónde va la educación', Esquiú, 692, 29 July 1973, p. 3.

77 Boletin de Comunicaciones del Ministerio de Educación y Cultura, 28 June 1973, p. 478. 
The democratic ethos that characterised Cámpora's government lasted only a short time. On 20 June i973, Juan Perón came back to the country. In what was the largest mobilisation in twentieth-century Argentina, more than a million people went to the airport to receive him. Unexpectedly, rightwing Peronists fired on their left-wing opponents, killing at least eight demonstrators and injuring 300. Right-wing Peronists soon gained positions of power, especially when Perón became president in October 1973. With Perón and, after July 1 974, his widow Isabel in office, a project to reconstitute 'authority' in all spheres of social life was accompanied by the creation of para-police groups such as the Alianza Anticomunista Argentina (Argentine Anti-Communist Alliance, AAA), based in the Ministry of Social Welfare and dedicated to murdering political and social militants. Beginning in 1974 , in addition, new legislation prohibited political activity in the universities and schools. At the end of that year, also, in response to the Montoneros' decision to resume guerrilla activities against a government that they called 'neither national nor popular', Isabel Perón decreed a 'state of siege', which restricted constitutional rights; it would last until 1983.

\section{Organising a 'Counter-Subversive' War}

The 'authority reconstitution' project involved a sexual and gender politics that repositioned conservative Catholic organisations at the forefront of decision-making bodies. In January 1974, the League of Mothers asked the police to curtail the circulation of novels such as Manuel Puig's The Buenos Aires Affair, because they 'violated the sense of morals'. While it is likely that, one year earlier, the League's claim would have gone unheard, now, as in the 'old days with Onganía', as one report indicated, the police entered bookstores, threw the novels out and imprisoned booksellers and publishers. ${ }^{7}$ The police carried our similar raids with regard to gay sociability and fashions, and the Frente de Liberación Homosexual (Homosexual Liberation Front) distributed a pamphlet cautioning readers on 'police efforts to reimpose a Cary Grant fashion' by cutting young men's hair and obliging them to wear 'sober and manly' clothes.79 Along the same lines, in mid-r 974 the never-dismantled Board of Film Qualification appointed a new president, the film critic Miguel Paulino Tato, who in only six months prohibited the release of 6I movies 'whose sexual or political content', he argued, 'would damage the already weakened internal

78 'La denuncia de una Liga de Madres impulsó a la Policía', La Opinión, 9 Jan. 1974, p. I 5.

79 'Comunicado del Frente de Liberación Homosexual', Somos No. I, Dec. 1973; 'Falta Onganía', No. 2, Feb. 1974, Frente de Liberación Homosexual Archive. 
front' ${ }^{80}$ Explicitly, sex and politics intermingled in his account, as they did in the rationale informing other major decisions.

Framed by a larger concern about 'Argentina's secular depopulation', in March 1974 Perón and his minister of social welfare, José López Rega, passed a decree that increased the requirements for purchasing contraceptive devices, notably the pill, and prohibited the promotion of all birth-control techniques in public hospitals. As Karina Felitti has shown, there is scant evidence concerning the evenness with which the decree was enforced and it is likely that it affected chiefly poor women, who relied on the public health system, in contrast to middle- and upper-class women who relied on the less closely monitored private system. ${ }^{81}$ In any case, in the public milieu of the mid-1970s, the rationale for the policy is significant since it enabled the rearticulation and broader dissemination of a discourse permeated by gender and sexual concerns. Taking up a common argument among conservative Catholic groups, the decree stated that birth control had 'distracted young people from their natural duties as protagonists of the future of the fatherland, and denaturalised women's maternal role'. ${ }^{82}$ Birth control represented the pernicious effects of 'liberalising' trends, which were embodied in young people's sexual mores and ended up by subverting the gender order entirely. Right-wing Peronists and conservative Catholics were in no doubt: young people potentially 'subverted' the sexual, gendered and political terrain. In their view, that dynamics corroded the 'future of the fatherland' and could only be countered by returning sex to its 'legitimate' role and site: procreation and marriage within a stable family.

The main actors within the conservative bloc intensified their appeal to the family as the antidote against 'subversion'. In late 1974, the Ministry of Social Welfare organised a large conference entitled 'Primer Encuentro Nacional de la Familia'. In his inaugural address, López Rega pointed out that 'guns, drugs and pornography are annihilating our nationhood', which could only be recovered, he said, through the 'reconstitution of the family'. Rather than a policy-making forum, the Encuentro set the scenario for staging a conservative discourse that touched on politics, culture and sexuality as they related to youth. ${ }^{83}$ It was also the background for the launching of an Episcopal Pastoral for the years 1975 and 1976 on 'Marriage and Family', an endeavour that resulted when the Catholic hierarchy unleashed a campaign to silence the voices of the radicalised lay-people and the Movement of Priests for

80 'Un Nuevo calificador', Clarín, 16 Sep. 1974, p. 36; 'Películas prohibidas', La Nación, 3 March 1975, p. 8.

${ }^{81}$ Karina Felitti, La revolución de la pildora (Buenos Aires: Edhasa, 201 2 ).

${ }^{82}$ Poder Ejecutivo Nacional, Decreto No. 659/74, Boletín Oficial, 3 March 1974, p. 2.

${ }_{3}$ 'El Primer Encuentro Nacional de la Familia', La Razón, 26 Nov. 1974, p. I. 
the Third World. ${ }^{84}$ For the depurated Catholic community, the defence of 'society's basic cell' seemed all the more urgent since, as the archbishop of Rosario argued, replicating the Ministry's tropes, in a well-publicised letter, 'our families are losing their youth to political violence, promiscuity, and drug addiction'. ${ }^{85}$ At that time, he did not answer the question of what to do with those youths 'already lost'. The armed forces had the answer.

In late 1974, when the Montoneros resumed guerrilla activities and their related political groups went into clandestinity, military ideologues also reinforced their 'counter-subversive' efforts. Brigadier D'Odorico, for example, explicitly combined ideas of national security with calls for reconstructing what he thought of as the vanishing social, gender and sexual order. In doing so, he justified the physical extermination of 'subversives'. The figure of the guerrilla woman came more and more to epitomise the various meanings of subversion. Hyperbolically revisiting his previous opinions, D'Odorico posited that 'she' was the final product of an ideological and political task through which the 'communists' took advantage of key female traits, such as 'sensibility, tenacity, tolerance to physical and spiritual pain, and passionate commitment'. In doing so, he argued, 'the enemy emptied her spiritual content, created a humanoid'. The 'guerrilla woman' had lost any trace of humankind and of womanhood. D'Odorico urged his peers to understand that 'in front of you, or more likely on your back, you will see a being that inhabits the empty body of a woman'. The conclusion was plain: the military or policemen might abandon their gender prejudices and, simply, shoot first. ${ }^{86}$

While these ideologues justified the physical extermination of 'subversive' young women - and men - the armed forces acted accordingly. Prudent estimates indicate that in 1975 alone, military, police and para-police forces assassinated 860 militants and activists. ${ }^{87} \mathrm{~A}$ daily linked to the Montoneros was the only newspaper informing readers about the gendered dynamics underpinning political repression. The head of the police section of the daily, the journalist and writer Rodolfo Walsh, accused police and para-police forces of constantly using rape as a 'threatening weapon' against female militants from all groups of the revolutionary spectrum. ${ }^{88}$ More dramatically, he informed readers that all the young female militants who had been assassinated had previously been raped, including Liliana Ivanoff, a teacher aged 22, who had participated in

84 'Programa de acción pastoral: matrimonio y familia', Boletín AICA, 956, i 7 April 1975, pp. 25-39.

85 'Peligro de dominación marxista', Boletín AICA, 981-2, 16 Oct. 1975, pp. 140-6.

${ }^{86}$ Comodoro José C. D'Odorico, 'La mujer en la guerrilla', Revista de la Escuela de Comando y Estado Mayor de la Fuerza Aérea Argentina, 78 (Oct. 1974), pp. 39-55.

${ }^{87}$ Gillespie, Soldiers of Perón, pp. 2 1 5-16.

88 'Auge del delito sexual', Noticias, 24 Feb. I974, p. 4; 'Violaron a una chica', Noticias, 7 June 1974, p. 22. 
the Montoneros' 'women's front', and María Tapia, a domestic worker aged i 9 , who had engaged with Juventud Peronista. ${ }^{89}$ To Brigadier D'Odorico, they were the 'guerrillas' that only inhabited the 'empty body of a woman'. His comrades within the armed forces, however, took dreadful sexual advantage of those bodies that they might have viewed as carriers of multiple subversions.

The conceptualisation of the 'enemy within' as a figure that subverted the political, gender and sexual orders not only informed particular forms of repression but also helped to construct a consensus for a military coup d'état that could re-establish 'order'. For example, in late 1975 the oldest women's magazine in Argentina, Para Ti, published a long report after a guerrilla group composed of young men and women - as the report highlighted - had killed a colonel and his wife. That middle-aged woman represented 'all of us... all the women of the fatherland who shout "enough"!' Unlike the 'guerrilla woman', the colonel's wife - who remained nameless in the report - stood for all that was deemed healthy and orderly in Argentina. Depicted as a good wife and mother, she died because one portion of the nation's young men and women had turned into 'assassins, the enemies of our values and morals'.$^{\circ}$ From a gendered perspective, Para Ti mobilised its readers' feelings and urged them to shout 'enough', a cry which in its immediate context meant, fundamentally, to demand the imposition of a 'strong' government. Scholars have often pointed out that the seemingly escalating political violence that swept across Argentina prompted the creation of that consensus, however reactive it might have been. ${ }^{91}$ The perception of the failure to resolve the so-called problem of violence was key to the welcoming of a 'strong' (that is, military) government. The main conservative actors embedded this perception into a broader politico-cultural struggle. In the most common representation, such as Para $T i$ s, the 'enemy' that jeopardised the nation was cause and effect of the erosion of society's fabric: the principles of hierarchy and discipline that resonated in the familial, gendered and sexual order.

\section{Conclusion: God, Family and Fatherland}

On 24 March 1976, the military coup d'état took place. As had happened in I 966, the junta drew on national security doctrines and conservative Catholic ideas to justify their decision to impose a coup. The military leaders proposed to unleash a 'missionary war' that was to be played out in the bodies and minds

89 'Liliana Ivanoff, Noticias, 27 April 1974, p. I3; 'Hallan otra joven muerta', Noticias, 3 June I974, p. 3; 'Horrible asesinato de una chica de la JP', Noticias, 7 July 1974, p. 9.

90 'Sépalo, señor extremista, usted no representa a nadie', Para Ti, 2788, i 5 Dec. 1975.

${ }^{91}$ For the notion of 'reactive consensus', see Marcos Novaro and Vicente Palermo, La última dictadura militar (1976-I983): del golpe de estado a la restauración democrática (Buenos Aires: Paidós, 2003). 
of those who were already 'enemies' and those who could be 'infected with the virus of subversion'. One week after the coup, president General Jorge Videla ( 1976-8I) defined what the junta took for subversion: 'it is not only planting bombs in the streets' but also 'all social conflict, the struggle between parents and children'.92 Restoring the principles of hierarchy and discipline was deemed crucial to winning over such a ubiquitous enemy, and it required enlisting all those who held positions of authority - parents, teachers and employers, to mention a few. Besides framing the enterprise, the junta assigned to the security forces the tasks of carrying out the most physical aspects of the presumed mission.

The Argentine military prioritised the mechanism of kidnapping, torturing and disappearing people as a method of restoring 'order'.93 Peaking in the biennium 1976-8, of the approximately 20,000 'disappeared' in the 340 clandestine detention centres run by the armed forces throughout the country, 69 per cent were between 16 and 30 years old. Whether they were students, employees or workers, most had been part of a network of militants and activists coming of age politically in the i 960 s and early I 9705.94 These young people represented the self-fulfilling prophecy that conservative Catholics, right-wing politicians, members of the armed forces and the dominant media had created since the early I 960 s: they were the 'enemy within' that the nation was ready to dispatch. In the dreadful conditions generated via the key mechanism of state terrorism, the armed forces also amplified the sexual and gendered components of violence. The rape of female prisoners was an intrinsic dimension of torture. As Elizabeth Jelin has written, it is only very recently that former prisoners and human rights activists have started to identify sexual violence as a violation of human rights in its own terms. This acknowledgment has paved the way for reconceptualising crimes and perpetrators.95 Looking from the vantage point of the medium-term and multi-layered making of the 'enemy within', sexual violence appears as a companion to the annihilation of an 'enemy' built up through the interweaving of political, gendered and sexual hazards. In order to prevent the resurgence of that sort of enemy, the military and their civilian allies aimed to revamp senses of authority and discipline, meant to 'start at home'.

At the same time as thousands of families were being destroyed by the disappearance of their members, the junta and other actors within the

92 'El primer mano a mano con el presidente', Gente, 560, is April 1976, p. 4.

93 Pilar Calveiro, Poder y desaparición: los campos de concentración en la Argentina (Buenos Aires: Colihue, 1997).

94 Argentine National Commission on the Disappearance of Persons, Nunca Más (Never Again) (London: Faber and Faber, 1986 [1984]), p. 285.

95 Elizabeth Jelin, 'Los abusos sexuales como crímenes de lesa humanidad y el respeto a la intimidad', Lucha Armada en la Argentina (201 I), pp. 4- 5 . 
conservative bloc appealed to a Catholic-based conservative ideal of patriarchal family as the guarantee of recovery of social order, which they viewed as profoundly damaged as a result of various medium-term dynamics. ${ }^{96}$ At the extreme end of the conservative bloc, far-right nationalists from the journal Cabildo cautioned the military not to conflate 'guerrilla' and 'subversion'. While the military were dedicated to struggling against the guerrillas, one editorial went on, they should also attack the bases of subversion: 'Distributing Bergman's and Pasolini's movies has been subversion. Allowing nudity on the stage and in advertisements, and promoting unisex fashion, has been subversion. The government's refusal to uphold the natural order based on the family has been subversive.' ${ }^{97}$ Focusing on those components of 'subversion' was not exclusive to the minority groups linked to Cabildo. Gente, the most widely read weekly at the time, delivered the same message when it tried to construct a historical interpretation of the spread of 'subversion'. The 'chaos' that Argentines had lived through in the wake of the military coup, one editorialist wrote, had begun not in 1973 but in the late I950s, 'when one culture tried to replace another'. That culture war had undermined the 'morals' of the younger generation, exposing them to 'badly digested psychoanalysis; ideas of a generation gap; images of sex and adultery; distorted ideas of what men's and women's duties and rights are; all mixed with claims of liberation'. Like other journalists, he blamed 'Argentine parents' for not having foreseen the effects of those occurrences and called them to join the 'vanguards of order'. ${ }^{8}$ In doing so, the media, the military and the Catholic hierarchy and family organisations not only reiterated a continuing anti-liberal and anti-communist litany but also appropriated it to produce a historical narrative of war in which they appeared as the contingent victors.

In two respects, though, that narrative contained kernels of truth: the ingredients at stake in the so-called war (culture, inter-generational relations, gender and sexuality) and the incipient periodisation of the 'culture war', dating back to the 1950s. Although building on anti-liberal and anticommunist traditions common to right-wing groups from the first half of the twentieth century, the bloc cemented in the 1950s around conservative Catholicism introduced new ideological and organisational developments. In particular, the Catholic family organisations, while talking in an old language that stressed the centrality of the patriarchal family, were a novelty in the political landscape. Created in the I950s, these groups tried to set limits to what they conceived of as the pernicious effects of modernising dynamics, including the increasing exposure of young people to new forms of

${ }^{96}$ See Judith Filc, Entre el parentesco y la politica (Buenos Aires: Biblos, 1997).

97 Demetrio Valdez, 'El deber frente a los caídos', Cabildo, 2 (Sep. 1976), pp. Iо- I I.

98 'Carta abierta a los padres argentinos', Gente, 595, 16 Dec. 1976, pp. 7-8. 
entertainment and sociability. All these, from their perspective, contributed to the erosion of the family's authority over the 'moral well-being' of youth. From the viewpoint of the conservative cultural bloc, the new socio-cultural developments of the late 1950 s and early i 960 s merited the reinforcement of the moral surveillance of the educational and cultural terrains - which is what occurred. With the exception of the period $1970-3$, the success of these groups in blockading policies (such as the establishment of psychological counselling in secondary schools) and delineating censorship, under either military or civilian governments, was remarkable. Groups such as the League of Mothers - whose membership rose to 80,000 in the early 1960s, their golden years - along with moral entrepreneurs such as Mario Fasano, carried out cultural and educational initiatives that were embedded in the belief that 'liberal' ideas and practices were the first step towards the erosion of authority and discipline and paved the way for communism. The same beliefs (originating in conservative Catholicism) spread among the military, partially due to the role that right-wing Catholic intellectuals played in their ideological formation.

The popularity of the ideological linkage between 'liberalism' and communism acquired its first momentum in the launching of the Revolución Argentina, which plainly aimed at deterring both. However, the extremism of the policies enforced (the barring of university autonomy and the morality campaigns), together with the news of worldwide cultural revolts, made that regime and its civilian allies appear decidedly out of step with the times. Political and social opposition to the regime mounted, and even the League of Mothers, attuned to the new ideas brought by the Second Vatican Council, partially criticised the Onganía regime and also welcomed young people's rising interest in conducting social work. However, neither the League nor any other conservative actors could tolerate the most radicalised overtones that political activism acquired after May 1969, which included the surfacing of guerrilla groups. The 'enemy within', so long imagined, appeared as a real threat. While the guerrilla groups indeed posed a threat to the political order, conservative Catholics, military ideologues and segments of the press added a gendered and sexual imagery. The 'guerrilla woman' as a figure epitomised the multiple threats, and served to emphasise the incompleteness of the politico-cultural project that the conservative bloc had tried to enforce throughout the 1960s. The conjuncture of 1973, moreover, tested the conservatives' worst fears and would act as a permanent reminder of how farreaching the 'chaos' could have been.

In the repressive backlash initiated in 1974, the gendered and sexual components of the 'enemy within' became prominent. The representation of social and political militants as carriers of sexual and gender disorders enhanced the perception of them as evil. In its circulation among the armed 
forces, this representation had dramatic effects, particularly for young female militants. However, as disseminated by the dominant media, it reached broader portions of Argentina's citizenry, mobilising fears of socio-cultural disintegration. By the same token, the perception of a chaotic situation that could eventually touch upon everyone's families paved the way for the shaping of demands for order. The military junta established in 1976 promised to restructure society under the banners of 'God, Family, and Fatherland'. In doing so, they were the heirs of a medium-term politico-cultural struggle where the conservative bloc tried both to set limits on attempts to change the social, cultural and political makeup of Argentina and to impose a project based upon respect for the principles of hierarchy, authority and property. When human rights groups at home and abroad campaigned to denounce the massive, state-led violation of human rights, Catholic organisations and the dominant media discredited what they dubbed an 'anti-Argentine campaign'. Most emblematically, in 1983 , when the transition towards a democratic political order was under way, the League of Mothers was one of the groups signing a public letter to pay homage to the military who, the letter asserted, had been victorious over 'subversion' and had done as much as possible to reconstitute 'morals and authority'. ${ }^{99}$ As it had been a decade earlier, however, in 1983 the conservative bloc, like the military, was merely defensive: it had backed away along with its main brainchild, the 'enemy within'.

\section{Spanish and Portuguese abstracts}

Spanish abstract. Este artículo estudia el desarrollo de un bloque conservativo amplio al interior de las batallas político-culturales que tuvieron lugar durante la Guerra Fría en Argentina. Centrándose en las poco exploradas dimensiones de género, sexuales y generacionales de la figura del 'enemigo interno', el artículo muestra que dicha idea estuvo en el corazón del proyecto que coincidió con las prácticas autoritarias del estado y también de ciertos segmentos de la sociedad civil. La creación de tal figura tuvo efectos significativos, no sólo en el área política, sino en la educativa y cultural, lo que incluyó la imposición de la censura y el delineamiento de políticas sexuales restrictivas. Más aún, condicionó las formas en la que se desarrolló la represión política en el contexto del terrorismo de estado de los i970s.

Spanish keywords: 'enemigo interno', Argentina, género y sexualidad, modernización, política derechista, terrorismo de estado

Portuguese abstract. Este artigo analisa o desenvolvimento de um amplo bloco conservador em meio às batalhas político-culturais que ocorreram durante a Guerra Fria na Argentina. Focando nos aspectos não explorados de gênero, sexo e geracional

99 'Por la patria', La Nación, 28 April 1983, p. 7. 
da figura do 'inimigo interno', o artigo demonstra que essa figura esteve no núcleo de um projeto que coincidiu com práticas autoritárias que emanavam do estado e também de segmentos da sociedade civil. A criação dessa figura teve efeitos significativos não apenas na esfera política, mas também nos setores educacional e cultural, incluindo a implementação da censura e o delineamento de políticas sexuais restritivas. Além disso, definiu as maneiras nas quais a repressão política desenvolveu-se no contexto de terrorismo de estado da década de 1970.

Portuguese keywords: 'inimigo interno', Argentina, gênero e sexualidade, modernização, políticas de direita, terrorismo estatal 